О. П. Плахотний, к.т.н., доцент,

дочент кафедри енерготехнологій

Черкаський державний технологічний університет

б-р Шевченка, 460, м. Черкаси, 18006, Україна

e-mail: pldecor@ukr.net

\title{
МОДЕЛЮВАННЯ ВПЛИВУ АМПЛІТУДНО-ЧАСОВИХ ПАРАМЕТРІВ ЕЛЕКТРИЧНИХ ІМПУЛЬСІВ НА ПРОЦЕСИ АНОДНОГО РОЗЧИНЕННЯ ПРИ ЕЛЕКТРОХІМІЧНІЙ ОБРОБЦІ ДРОТЯНИМ ЕЛЕКТРОДОМ
}

Комбінована технологія послідовного використання електроерозійної та електрохімічної обробки дротяним електродом дозволяє отримувати якісну поверхню і формувати металеві компоненти з високою точністю, незалежно від міцності та твердості матеріалів. Застосування імпульсного струму для електрохімічної обробки значно підвищує керованість процесу. В роботі наведено математичну модель масопереносу в дифузійному прианодному шарі, яка разом з розрахунком розподілу густини струму для схеми ииліндричний катод - плоский анод дає можливість обтрунтованого вибору амплітудно-часових параметрів електричних імпульсів. Це забезпечує досягнення максимального показника виходу за струмом і точне прогнозування товщини знятого шару при електрохімічній обробиі поверхні рухомим дротяним електродом. Проведені експериментальні дослідження по апробачії розрахункової методики показали, щяо теоретичні розрахунки добре узгоджуються з експериментальними даними. Запропонований спосіб дозволяє підвищити ефективність електрохімічного фінішування поверхні після електроерозійної вирізної обробки.

Ключові слова: електроерозійна вирізна обробка, дротяна електрохімічна обробка, дротяний електрод-інструмент, міжелектродний проміжок, приповерхневі явища, дифузійний шар.

Вступ. Електроерозійна вирізна обробка (ЕЕВО) широко використовується в інструментальному виробництві, при виготовленні штампів, пресформ, деталей машин. Висока точність і відсутність механічних навантажень на заготовку зумовлюють застосування технології в мікрообробці. Однак на поверхні деталі залишається термічно змінений шар внаслідок дії високих градієнтів температури, спричинених іскровими розрядами в процесі EEBO, який у багатьох випадках $\epsilon$ небажаним явищем [1]. Швидке охолодження матеріалу з розплавленого стану призводить до появи на поверхні білого шару, в якому локалізуються залишкові напруження, що, в свою чергу, ініціює появу тріщин при навантаженні компонента на згин [2]. Для багатьох галузей сучасної промисловості наявність подібних поверхневих шарів $€$ неприпустимою. Тому дослідження, присвячені модифікації поверхонь після ЕЕВО, є актуальними.

Аналіз літературних даних та постановка проблеми. Найбільш близькою до ЕEВО є електрохімічна вирізна обробка дротяним електродом, при якій відсутнє теплове навантаження на деталь. Але на сьогодні ця технологія достойну конкуренцію ЕЕВО скласти не може через меншу продуктивність різання [3]. Проблемним питанням тут є створення напору електроліту в малому міжелектродному проміжку (МЕП) закритого вузького паза. Інтенсифікація потоку електроліту i прискорення масопереносу при анодному розчиненні можлива за рахунок застосування вібраційного ребристого дротяного електрода [4]. Але це суттєво ускладнює технологічну схему і призводить до послаблення контролю за процесом.

Найбільш вдалим, перспективним є поєднання електроерозійної та електрохімічної технологій при їх послідовному застосуванні $[5,6]$. При комбінованій технології електроерозійної та електрохімічної обробки дротяним електродом деталь виготовляється за одну установку на електроерозійному верстаті одним і тим же електродом-інструментом [7]. При цьому використовуються висока точність і продуктивність ЕЕВО та високі показники якості вихідної поверхні після електрохімічної обробки. 
Потужним ресурсом у керуванні процесами електрохімічного розчинення є можливість варіювання амплітудно-частотними параметрами імпульсного технологічного струму. Дозованість підведеної енергії до електродів дає можливість застосовувати імпульсну електрохімічну обробку для виготовлення мікророзмірних деталей, де необхідна висока точність і керованість процесу.

Правильний вибір амплітудно-часових параметрів імпульсного струму при практичному застосуванні електрохімічного фінішування поверхні дає значний ефект. Так, електрополірування трубчастої поверхні сталі $\mathrm{SS} 316$ в електроліті $\mathrm{NaCl} / \mathrm{NaNO}_{3}$ протягом 45 секунд покращило шорсткість поверхні 3 $\mathrm{Ra}=1$ мкм до дзеркального вигляду з фіналом $\mathrm{Ra}=0,026$ мкм [8]. Експериментальні дослідження по фінішуванню деталей з підшипникової сталі $\mathrm{GCr} 15$ в суміші розчинів $\mathrm{NaCl}$ i $\mathrm{NaNO}_{3}$ дали можливість підібрати такі режими імпульсного струму, що забезпечили покращення шорсткості поверхні з $\mathrm{Ra}=1,6$ мкм до $\mathrm{Ra}=0,12$ мкм [9].

Кількісне моделювання при імпульсній електрохімічній мікрообробці проводять на основі заміщення міжелектродного проміжку еквівалентними електричними схемами [10] або на основі розв'язку системи диференціальних рівнянь масопереносу в електричному полі заряджених реагуючих іонів та рівняння Пуассона для електростатичного потенціалу поля з урахуванням відповідних початкових і граничних умов [11]. Однак для технологічної схеми дротяний циліндричний катод - плоский анод такі математичні моделі не адаптовані.

Мета роботи - розробити математичну модель та провести ï експериментальну апробацію для обгрунтованого вибору амплітудночасових параметрів імпульсного струму, який забезпечить ефективність процесу анодного розчинення при комбінованої технології електроерозійної та електрохімічної обробки дротяним електродом.

Виклад основного матеріалу дослідження. Електрохімічна обробка (ЕХO) $є$ певним типом електролізу з дією електричного струму, що проходить через електроліт у гальванічному елементі. Деталь, що обробляється, служить анодом. Струм, що подається ззовні, проходить від анода до катода, приводить до видалення поверхневих шарів металу, які розчиняються в електроліті, стають катіонами і прямують до катода. При електрохімі- чній обробці використовують такі електроліти, матеріали анода (переважно сталі) та катода (латуні), катіони яких не осідають на поверхні катода. Таким підбором забезпечується основна перевага ЕХО - незмінність форми електрода-інструмента [13]. Кількість видаленого металу залежить від розчину електроліту, температури, густини струму і електрохімічного еквіваленту матеріалу заготовки. Зазвичай амплітуда струму і час - дві керовані змінні для здійснення контрольованого перебігу процесу і досягнення необхідних показників поверхні деталі. Граничні обмеження керованості цих змінних пов'язані з механізмами процесів, які відбуваються на поверхні металу при ЕХО (рис. 1). Вважається [12], що інтенсивність анодного розчинення може бути обмежена масопереносом, а саме, дифузією іонів металу, що розчиняються, акцепторних компонентів 3 електроліту та молекул води. На поверхні анода утворюється пористокомпактна соляна плівка. Причому, утворення компактного сольового шару товщиною близько 10 нм відбувається переважно на дні впадин, і рух іонів у ньому здійснюється завдяки наявності високого електричного поля. Цей шар має великий опір через низьку рухомість іонів у твердому стані. Далі знаходиться пористий шар плівки товщиною близько кілька мікронів, заповнений електролітом, насиченим іонами металів, що розчинилися. В сукупності ці компактно-пористі шари становлять адсорбційний подвійний шар (рис. 1). Густина струму контролюється підходом акцепторних іонів до поверхні шару, тобто процесами масопереносу в дифузійному шарі, який розташований далі. Катіони металу, що виділяються і адсорбуються на поверхні подвійного шару, видаляються (сольватуються) акцепторними іонами, які дифундують до поверхні. В стаціонарному стані дії електричного поля концентрація акцепторних іонів у дифузійному шарі менша, ніж в об'ємі електроліту і на межі електрод/електроліт набуває значення, близького до нуля, якщо іони споживаються, як тільки доходять до поверхні. Концентрація катіонів металу, навпаки, зростає, відбувається блокування поверхні цими адсорбованими іонами, що призводить до виникнення надпотенціалу перенапруження. Це, в свою чергу, ініціює сторонні хімічні реакції, що споживають частину кількості затраченої електрики, і ефективність основного процесу розчинення падає, змінюється якість обробленої поверхні. 


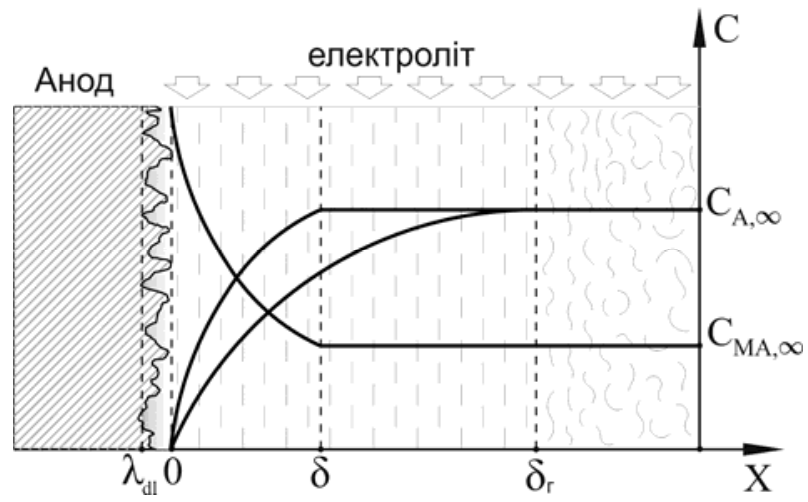

Рис. 1. Розподіл концентрації акцепторних іонів $C_{A}$ i адсорбованих іонів металу $C_{M A}$

в електроліті біля поверхні анода: $\lambda_{\mathrm{dl}}$ - товщина адсорбційного подвійного шару,

$\delta$ - товщина дифузійного шару, $\delta_{\Gamma}-$ товщина гідродинамічного пограничного шару [12]

Місцева густина струму на аноді, яка залежить від значення амплітуди імпульсів струму, $є$ дуже важливим параметром для контролю за процесом розчинення. Для конфігурації циліндричний дротяний катод плоский анод такий розподіл описується аналітичними формулами. При поверхневій обробці підбирають такий склад і концентрацію електролітів, щоб досягти більшої густини струму на виступах порівняно 3 впадинами i досягти вирівнювання поверхні завдяки переважному розчиненню виступів. Важливим завданням $€$ забезпечення достатньої густини струму для рухомості іонів у в'язкому адсорбційному подвійному шарі. Але збільшення амплітуди струму викликає необхідність скорочувати час дії імпульсу через більш швидке виникнення дифузійних обмежень. Тому кількісні моделі розподілу густини струму і дифузійних процесів у МЕП $є$ дієвим інструментом для керування процесами поверхневого анодного розчинення.

Математична модель масопереносу в прианодних шарах електроліту при ЕХО. Математична модель базується на розв'язку нестаціонарної задачі дифузії в приелектродній області (рис. 1), який описує коливання концентрації $C(x, t)$ реагуючих іонів в електроліті внаслідок дії періодичного струму. Для двокомпонентних електролітів типу $\mathrm{NaCl}$, $\mathrm{NaNO}_{3}$ розглядаються $C_{l}(x, t)$ - концентрація натрію (катіони), $C_{2}(x, t)$ - концентрація хлору (аніони) та $D_{1}, D_{2}$ - коефіцієнти дифузії відповідно натрію і хлору.

Приймемо наступні спрощення: розчин електроліту має достатньо інертні іони солі, тому потоком міграції іонів внаслідок дії електричного поля можна знехтувати; фізичні параметри електроліту постійні; дія сил тяжіння в області дифузії незначна; в об'ємі електроліту не відбуваються хімічні реакції. Період імпульсів повинен бути довшим, ніж час зарядки-розрядки подвійного електричного шару, який зазвичай триває кілька мікросекунд. За таких умов рівняння дифузії має вигляд [14]:

$$
\frac{\partial C}{\partial t}+\vec{v} \cdot \vec{\nabla} C=D \nabla^{2} C
$$

Початкові та граничні умови:

$$
\begin{aligned}
& C=C_{\infty} \text { при } t=0 ; \\
& C=C_{\infty} \text { при } x \rightarrow \infty ; \\
& \frac{\partial C}{\partial x}=\frac{i(t)}{n F D} \text { при } x=0 ;
\end{aligned}
$$

де $D$ - коефіцієнт дифузії іонного компонента, $\vec{v}$ - швидкість електроліту, $C_{\infty}-$ значення концентрації далеко від електрода (в об'ємі електроліту), $n$ - кількість електронів, які перенесені в електродній реакції, $F=9,65 \cdot 10^{4}$ Кл/моль - число Фарадея.

Для малих періодів імпульсів струму в тонких приелектродних шарах, які знаходяться всередині гідродинамічного пограничного шару (рис. 1), внесок конвективної складової $\vec{v} \cdot \vec{\nabla} C \epsilon$ незначним $[14,15]$. Тому рівняння (1) можна спростити:

$$
\frac{\partial C}{\partial t}=D \nabla^{2} C .
$$

Представимо імпульсний струм (рис. 2), який проходить через поверхню розділу електрод/електроліт, у вигляді суми усередненої по часу постійної складової $i_{d c}$ і змінної складової коливального струму $i_{a c}$ :

$$
i(t)=i_{d c}+i_{a c}(t),
$$

тут середня постійна густина струму

$$
i_{d c}=\frac{i_{1} t_{1}}{T} .
$$




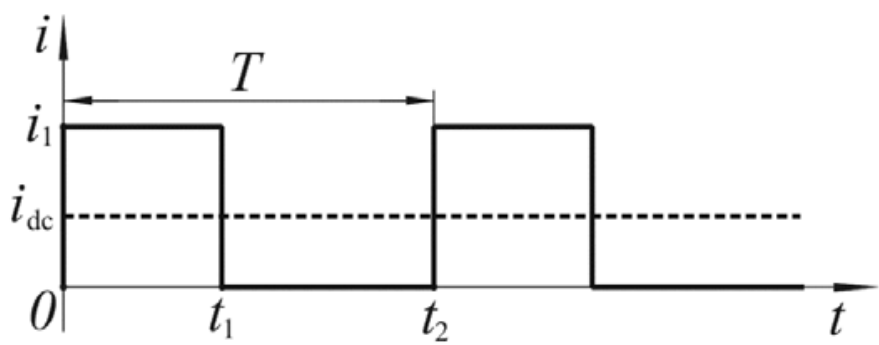

Рис. 2. Форма технологічних імпульсів струму $i(t)$ при EXO

Змінна густина струму на двох ділянках

$$
i_{a c}(t)=\left\{\begin{array}{l}
i_{1}-i_{d c} \text { при } 0<t<t_{1}, \\
-i_{d c} \text { при } t_{1}<t<t_{2} .
\end{array}\right.
$$

Аналогічно можна розкласти концентрацію

$$
C(x, t)=\bar{C}(x)+\widetilde{C}(x, t),
$$

де $\bar{C}(x)$ - стала концентрація, що встановилася, $\widetilde{C}(x, t)$ - змінна концентрація.

За умови (7) із рівнянь (2), (3) одержимо два рівняння для $\bar{C}(x)$ та $\widetilde{C}(x, t)$ з відповідними граничними та початковою умовами.

Рівняння для $\bar{C}(x)$ :

$$
\frac{\partial^{2} \bar{C}}{\partial x^{2}}=0
$$

за умов

$$
\begin{aligned}
& \bar{C}=C_{\infty} \text { при } x \geq \delta, \\
& \frac{\partial \bar{C}}{\partial x}=-\frac{i_{d c}}{n F D} \text { при } x=0 .
\end{aligned}
$$

Розв'язком рівняння (8) буде:

$$
\bar{C}(x)=C_{1} x+C_{2},
$$

де $C_{1}, C_{2}$ - сталі інтегрування. Задовольнивши умови (9) і (10), отримаємо:

$$
C_{1}=-\frac{i_{d c}}{n F D}, \quad C_{2}=C_{\infty}+\frac{i_{d c}}{n F D} \delta
$$

Тому розв'язок рівняння (8) набуде наступного вигляду:

$$
\begin{aligned}
& \bar{C}(x)=-\frac{i_{d c}}{n F D} x+C_{\infty}+\frac{i_{d c}}{n F D} \delta . \\
& \text { Знайдемо }\left.\bar{C}\right|_{x=0}=C_{\infty}+\frac{i_{d c}}{n F D} \delta . \text { В гра- }
\end{aligned}
$$
ничному випадку при $i_{d c}=i_{\lim }$ буде $0=C_{\infty}+\frac{i_{\text {lim }}}{n F D} \delta$, звідки

$$
i_{\lim }=-\frac{n F D C_{\infty}}{\delta}
$$

- обмежуюча величина густини постійного струму [12].

В літературі наведені різні формули для визначення товщини дифузійного шару. При потенціостатичному режимі: $\delta_{n}=\sqrt{\pi D t_{1}}[16]$; при гальваностатичному режимі: $\delta_{2}=2 \sqrt{\frac{D t_{1}}{\pi}}$ $[12,16,17]$; $з$ урахуванням швидкості $v$ руху електроліту по електроду: $\delta=\frac{1}{2} \sqrt{\frac{v H}{v}} \cdot\left(\frac{D}{v}\right)^{\frac{1}{3}}$, де $v$ - кінематична в'язкість електроліту, $H$ відстань від початку контакту потоку, що набігає, з поверхнею анода [16].

Для коливальної частини концентрації $\widetilde{C}(x, t)$ отримуємо рівняння:

$$
\frac{\partial \widetilde{C}}{\partial t}=D \nabla^{2} \widetilde{C}
$$

з умовами:

$\widetilde{C}=0$ при $x=\delta$,

$$
\widetilde{C}=0 \text { при } t=0 \text {, }
$$

$$
\frac{\partial \widetilde{C}}{\partial x}=-\frac{i_{a c}(t)}{n D F} \text { при } x=0 \text {. }
$$

Задача (14), (15) розв'язується з використанням перетворення Лапласа $[15,18]$. Поверхнева змінна концентрація:

$$
\widetilde{C_{s}}(t)=-\frac{1}{n F} \int_{0}^{t} Y(t-u) \cdot i_{a c}(u) d u,
$$

де $Y(t)=\frac{2}{\delta} \sum_{m=1}^{\infty} e^{-\frac{\pi^{2} D}{\delta^{2}}\left(m-\frac{1}{2}\right) t}$.

Введемо безрозмірні величини: 
$C^{*}=\frac{C}{C_{\infty}}, C_{s}^{*}=\frac{C_{s}}{C_{\infty}}, \overline{C_{s}^{*}}=\frac{\overline{C_{s}}}{C_{\infty}},{\widetilde{C_{s}}}_{s}^{*}=\frac{\widetilde{C_{s}}}{C_{\infty}}, t^{*}=\frac{t}{T}, \mathrm{~T}^{*}=\frac{D T}{\delta^{2}}$, $\theta_{1}=\frac{t_{1}-0}{T}, \theta_{2}=\frac{t_{2}-t_{1}}{T}, i_{P L}^{*}=\frac{i_{P L}}{i_{\lim }}, i_{1}^{*}=\frac{i_{1}}{i_{\lim }}, i_{a c}^{*}=\frac{i_{a c}}{i_{\lim }}, i_{d c}^{*}=\frac{i_{d c}}{i_{\lim }}$,

де $\theta$ - сквапність, $i_{\mathrm{PL}}-$ гранично допустима густина струму, при якій поверхнева концентрація $C_{s}=0$. Тоді згідно з (7) повна безрозмірна поверхнева концентрація:

$$
C_{s}^{*}=1-i_{d c}^{*}-\frac{1}{n F C_{\infty}} \int_{0}^{t^{*}} Y\left(t^{*}-u\right) \cdot i_{a c}(u) d u .
$$

Формула (18) свідчить, що $C_{s}^{*}$ зменшується за рахунок середнього струму $i_{d c}$ та змінного струму $i_{a c}(t)$. У формулі (18) згідно 3 (6) $i_{a c}(t)$ стала для кожної ділянки (рис. 2), тому обрахунок інтегралу слід вести по ділянках. Отримаємо $\Psi_{1}, \Psi_{2}$ значення інтегралу по ділянках:

$$
\begin{aligned}
& \Psi_{1}=2 T^{*} \sum_{m=1}^{\infty} \frac{1}{\lambda_{m}}\left\{\left[1-e^{-\lambda_{m} t_{1}^{*}}\right]\right\} \text { при } 0<t^{*}<t_{1}^{*}, \\
& \Psi_{2}=2 T^{*} \sum_{m=1}^{\infty} \frac{1}{\lambda_{m}}\left\{\left[1-e^{-\lambda_{m} t_{2}^{*}}\right]-\left[1-e^{-\lambda_{m} t_{1}^{*}}\right]\right\} \text { при } \mathrm{t}_{1}^{*}<t^{*}
\end{aligned}
$$

$$
\text { тут } \lambda_{m}=\pi^{2} T^{*}\left(m-\frac{1}{2}\right)^{2} \text {. }
$$

При малих значеннях $T$ власні числа $\lambda_{m}$ набуватимуть малих значень і ряди у формулах (19) будуть збігатися повільно. Щоб спростити (19), винесемо за знак $\Sigma$ параметри, що не залежать від $m$, та врахуємо, що $\sum_{n=1}^{\infty} \frac{1}{(2 n-1)^{2}}=\frac{\pi^{2}}{8}$. Отримаємо:

$$
\Psi_{1}=1-\frac{2}{\pi^{2}} \sum_{m=1}^{\infty} \frac{1}{\left(m-\frac{1}{2}\right)^{2}} e^{-\lambda_{m} t_{1}^{*}},
$$$$
\Psi_{2}=\frac{2}{\pi^{2}} \sum_{m=1}^{\infty} \frac{1}{\left(m-\frac{1}{2}\right)^{2}}\left(e^{-\lambda_{m} t_{1}^{*}}-e^{-\lambda_{m} t_{2}^{*}}\right) \text {. }
$$

Загальна безрозмірна поверхнева концентрація набуде вигляду:

$$
C_{s}^{*}=1-\frac{i_{d c}}{i_{\lim }}-\left(\frac{i_{1}-i_{d c}}{i_{\lim }} \Psi_{1}+\frac{i_{d c}}{i_{\lim }} \Psi_{2}\right) .
$$

Прирівняємо до нуля $C_{s}^{*}$ у формулі (21) та знайдемо допустиму густину струму $i_{P L}=i$ при $C_{s}^{*}=0$ та при $t^{*}=t_{1}^{*}, t_{2}^{*}$, тобто в кінці кожної ділянки $[15,18]$.

Для прямокутного імпульсу (рис. 2), де навантажена перша ділянка, отримаємо:

$$
i_{P L}=\frac{i_{\lim }}{\theta_{1}+\left(1-\theta_{1}\right) \Psi_{1}} .
$$

Для ефективної обробки 3 максимальним значенням коефіцієнта виходу за струмом необхідне виконання умови

$$
i_{\text {max }} \approx i_{P L},
$$

де $i_{\max }$ - максимальне значення густини струму на поверхні деталі для конкретної конфігурації електродів технологічної схеми ЕХО. У нашому випадку - це циліндричний дротяний катод і плоский анод, для яких розподіл напруженості електричного поля і густини струму обраховується за аналітичними формулами $[7,19,20]$.

Вимогу (23) можна задовольнити, змінюючи технологічні параметри - напругу на електродах, величину міжелектродного проміжку, діаметр дротяного електрода, концентрацію електроліту, а також за рахунок вибору $t_{1}, T$, розв'язавши рівняння (22) відносно $\theta_{1}$.

Експериментальні дослідження ефективності анодного розчинення. Для узгодження розрахункової моделі з реальним технологічним процесом електрохімічної обробки дротяним електродом проведено серії експериментів. Використовувались дві технологічні схеми - 3 нерухомим електродом (рис. 3), в результаті розчинення утворювалась вертикальна канавка на поверхні деталі, $\mathrm{i}$ 3 рухомим електродом (рис. 4), відбувалося розчинення поверхневого шару деталі певної товщини.

Експерименти електрохімічної обробки поверхні деталі висотою 11,5 мм (матеріал заготовки - штампова сталь Х12Ф1) проводились у середовищі електроліту $1 \mathrm{M} \mathrm{NaCl}$ при температурі $37-42^{\circ} \mathrm{C}$. Як катод використовувався латунний дріт (ДКРПМ ФКТЛ63) діаметром 0,2 мм. Величина міжелектродного зазору варіювалася в межах 0,2-0,4 мм; напруга, підведена в міжелектродний проміжок, вибиралася в межах 4-12 В; тривалість електричних імпульсів становила $0,2-5$ мс, сквапність - 20-50\%, загальний час дії електрохімічного розчинення становив 240-900 с для нерухомого електрода, швидкість подачі - 0,63,5 мм/хв. для експериментів з рухомим електродом. 
Ефективність електрохімічного розчинення для різних амплітудно-часових параметрів імпульсів визначалася за коефіцієнтом виходу за струмом при зіставленні експериментальних і теоретично розрахованих показників.

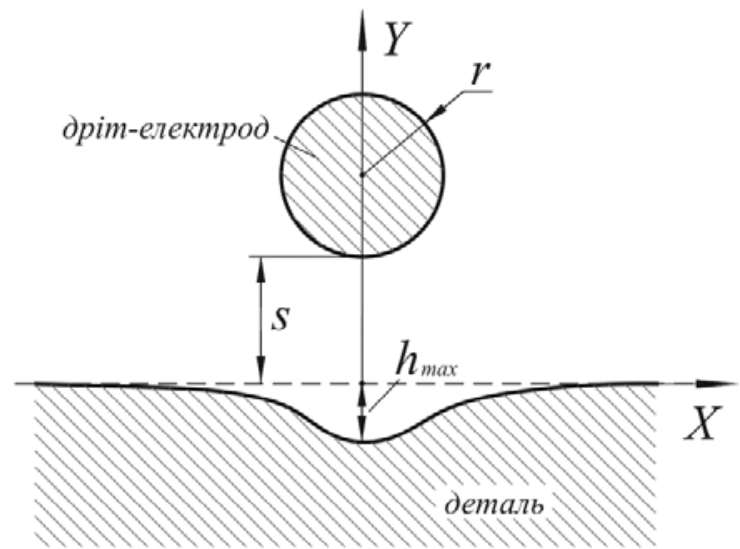

Рис. 3. Отримання канавки на поверхні деталі в результаті анодного розчинення з нерухомим катодом

Для експериментів 3 нерухомим катодом коефіцієнт виходу за струмом $\eta=\frac{h_{\text {екс }}}{h_{\max }}$, де

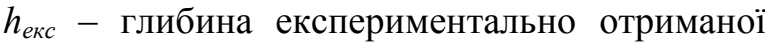
канавки, $h_{\max }$ - розрахункова глибина канавки. Теоретичний розрахунок проводився за формулами [7, 19]:

$$
h_{\max }=\frac{2 U \kappa}{a \ln (p)} K_{v} \frac{t_{1}}{T} t, a=\sqrt{2 r s+s^{2}}, \quad p=\frac{a-s}{a+s} ;
$$

де $U$ - напруга на електродах, $\kappa$ - провідність електроліту, $K_{v}$ - електрохімічний еквівалент матеріалу анода, $t_{1}, T$ - тривалість $i$ час імпульсу струму відповідно, $t$ - загальний час роз- чинення, $r$ - радіус дроту-електрода, $s$ - величина міжелектродного проміжку.

Максимальна густина струму

$$
i_{\max }=\frac{2 U \kappa}{a \ln (p)} .
$$

В табл. 1 наведено амплітудно-часові параметри імпульсів струму, розраховані значення допустимої густини струму $i_{P L}$ та значення коефіцієнта виходу за струмом $\eta$ для експериментів 3 нерухомим катодом. Результати свідчать, що при відхиленні величини максимальної густини струму $i_{\max }$, реалізованої в експерименті, від розрахованої $i_{P L}$ коефіцієнт виходу за струмом падає.

Результати обчислення коефіціснта виходу за струмом

Таблиця 1

\begin{tabular}{|c|c|c|c|c|c|}
\hline $\begin{array}{c}\text { Код } \\
\text { експерименту }\end{array}$ & $i_{\max }, \mathrm{A} / \mathrm{cm}^{2}$ & $t_{l}, \mathrm{Mc}$ & $T$, мс & $i_{P L}, \mathrm{~A} / \mathrm{cm}^{2}$ & $\eta$ \\
\hline $6 \mathrm{~K} 1$ & 5,6 & 2 & 8 & 6,95 & 0,96 \\
\hline $6 \mathrm{~K} 2$ & 14,97 & 2 & 8 & 6,95 & 0,64 \\
\hline $6 К 3$ & 31,08 & 2 & 8 & 6,95 & 0,48 \\
\hline $6 К 4$ & 30,91 & 2 & 4 & 6,04 & 0,38 \\
\hline $6 К 5$ & 28,9 & 1 & 2 & 8,54 & 0,43 \\
\hline
\end{tabular}
в експериментах 3 нерухомим катодом 


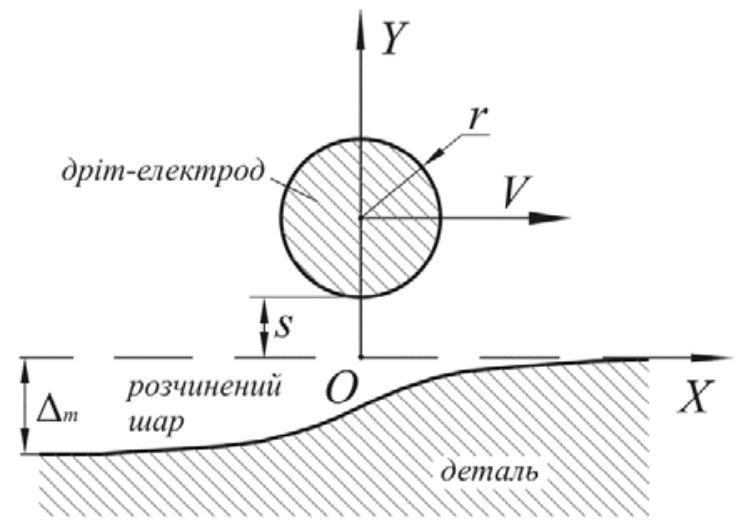

Рис. 4. Анодне розчинення поверхневого шару деталі з рухомим катодом

Для технологічної схеми 3 рухомим дротяним електродом розрахунки проводились за наступними формулами [20]. Коефіцієнт виходу за струмом

$$
\eta=\frac{\Delta_{e \kappa c}}{\Delta_{\mathrm{m}}}
$$

де $\Delta_{\text {екс }}$ - виміряна товщина розчиненого шару в результаті експерименту, $\Delta_{\mathrm{m}}-$ розрахункова товщина розчиненого шару: $\Delta_{m}=\frac{2 \pi U \kappa K_{v}}{V \ln (p)}$, $V$ - швидкість руху дротяного електрода.

$$
i_{\max }=\frac{2 U \kappa}{a \ln (p)} .
$$

3 рухомим дротяним електродом проведено серії експериментів. Найбільш переконливі результати наведено в табл. 2. В експерименті 1П9 значення $i_{\max }$ близьке до розрахованої величини $i_{P L}$ i отримано високу ефективність ЕХО з коефіцієнтом виходу за струмом 0,9. А в експерименті 4П6(1) так вибрані технологічні параметри, що $i_{\max }$ майже в 3 рази перевищує допустиме значення $i_{P L}$ i маємо низьку ефективність процесу 3 коефіцієнтом виходу за струмом 0,15 .

Таблиця 2

\section{Результати обчислення коефіціснта виходу за струмом} в експериментах з рухомим катодом

\begin{tabular}{|c|c|c|c|c|c|}
\hline $\begin{array}{c}\text { Код } \\
\text { експерименту }\end{array}$ & $i_{\max }, \mathrm{A} / \mathrm{cm}^{2}$ & $t_{1}, \mathrm{Mc}$ & $T, \mathrm{Mc}$ & $i_{P L}, \mathrm{~A} / \mathrm{cm}^{2}$ & $\eta$ \\
\hline $1 П 9$ & 4,59 & 5 & 10 & 4,68 & 0,90 \\
\hline $4 \Pi 6(1)$ & 35,0 & 2 & 10 & 11,7 & 0,15 \\
\hline
\end{tabular}

3 підвищенням густини струму в експериментах з рухомим катодом спостерігалась загальна тенденція до зменшення шорсткості вихідної поверхні. Однак в експерименті 4П6(1) через значне порушення умови (23) отримали не тільки низьку ефективність виходу за струмом, але й гіршу якість поверхні порівняно з експериментом 1П9, де застосовувалась менша густина струму. Це означає, що побічні реакції, на які витрачається частина електричної енергії, призводять тільки до погіршення якості обробленої поверхні. Отже, для отримання якісної поверхні 3 низькою шорсткістю слід підвищувати густину струму, обов'язково зважаючи на вимоги наведеної вище розрахункової методики. Крім того, встановлений коефіцієнт виходу за струмом забезпечує точне прогнозування товщини знятого шару (термічно зміненого внаслідок електроерозійних іскрових розрядів) при застосуванні ЕХО в складі комбінованої електрохімічної і електроерозійної обробки дротяним електродом.

\section{Висновки}

1. У ході теоретично-експериментальних досліджень процесів анодного розчинення при електрохімічній обробці дротяним електродом встановлено, що розроблена математична мо- 
дель дифузії в прианодних шарах дає можливість розрахувати технологічні параметри, які забезпечать максимальну ефективність ЕХО по виходу за струмом. Проведені зіставлення результатів експериментів з дотриманням теоретичних рекомендацій і з відхиленням від них доводять, що створена методика дає можливість виконати обгрунтований вибір амплітудно-часових параметрів при проектуванні технологічних процесів електрохімічної обробки дротяним електродом.

2. Запропонований підхід 3 використанням математичного моделювання дає можливість у перспективі перейти до застосування більш складних форм імпульсів технологічного струму, що надасть додаткові важелі в керуванні процесами в МЕП для покращення якості вихідної поверхні внаслідок анодного розчинення дротяним електродом.

\section{Список літератури}

1. Straka L., Čorný I., Pitel' J. Properties evaluation of thin microhardened surface layer of tool steel after wire EDM. Metals. 2016. V. 6, № 5. P. 95.

2. Klocke F., Hensgen L., Klink A., Ehle L., Schwedt A. Structure and composition of the white layer in the wire-EDM process. Procedia CIRP. 2016. V. 42. P. 673-678.

3. Debnath S., Kundu J., Bhattacharyya B. Modeling and influence of voltage and duty ratio on wire feed in WECM: possible alternative of WEDM. Journal of the Electrochemical Society. 2018. V. 165, № 2. P. E35-E44.

4. Zou X., Fang X., Chen M., Zhu D. Investigation on mass transfer and dissolution localization of wire electrochemical machining using vibratory ribbed wire tools. Precision Engineering. 2018. V. 51. P. 597-603.

5. Skoczypiec S. Discussion of ultrashort voltage pulses electrochemical micromachining: a review. The International Journal of Advanced Manufacturing Technology. 2016. V. 87, № 1-4. P. 177-187.

6. Skoczypiec S., Ruszaj A. A sequential electrochemical-electrodischarge process for micropart manufacturing. Precision Engineering. 2014. V. 38, № 3. P. 680-690.

7. Osipenko V.I., Plakhotny A. P., Denisenko A. Yu. Improved methodology for calculating the processes of surface anodic dissolution of spark eroded recast layer at electro- chemical machining with wire electrode. Праці Одеського політехнічного універcumemy. 2014. Вип. 1 (43). С. 55-60.

8. Taylor E. J., Inman M. Electrochemical surface finishing. The Electrochemical Society Interface. 2014. V. 23, № 3. P. 57-61.

9. Zheng X. H., Wei Z. F., Huang S. Experiment study of pulse electrochemical finishing of GCr15 bearing steel. Advanced Materials Research. 2013. V. 705. P. 203-208.

10. Kozak J., Gulbinowicz D., Gulbinowicz Z. The mathematical modeling and computer simulation of pulse electrochemical micromachining. Engineering Letters. 2008. V. 16, № 4. P. 556-561.

11. Kumsa D., Scherson D. A. Theoretical aspects of pulsed electrochemical micromachining. Journal of The Electrochemical Society. 2013. V. 160, № 8. P. H481-H488.

12. Yang G., Wang B., Tawfiq K., Wei H., Zhou S., Chen G. Electropolishing of surfaces: theory and applications. Surface Engineering. 2016. V. 33, № 2. P. 149-166.

13. Справочник по электрофизическим и электрохимическим методам обработки / [ред. В. А. Волосатов]. Москва: Машиностроение, 1988. 719 с.

14. Smets N., Van Damme S., De Wilde D., Weyns G., Deconinck J. Time-averaged concentration calculations in pulse electrochemical machining, spectral approach. Journal of applied electrochemistry. 2009. V. 39, № 12 . P. 2481-2488.

15. Chin D. T. Mass transfer and currentpotential relation in pulse electrolysis. Journal of the Electrochemical Society. 1983. V. 130, № 8. P. 1657-1667.

16. Bagotsky V. S. Fundamentals of electrochemistry. 2nd ed. John Wiley \& Sons, Inc.: Hoboken, NJ., 2005. 722 p.

17. Purushothaman B., Morrison P., Landau U. Reducing mass-transport limitations by application of special pulsed current modes. Journal of the Electrochemical Society. 2005. V. 152, № 4. P. J33-J39.

18. Choo R., Toguri J., El-Sherik A., Erb U. Mass transfer and electrocrystallization analyses of nanocrystalline nickel production by pulse plating. Journal of applied electrochemistry. 1995. V. 25, № 4. P. 384-403.

19. Осипенко В. И., Плахотный А. П., Билан А. В. Исследование процессов съема материала при электрохимической размерной обработке проволочным электро- 
дом. Вісник СевНТУ: зб. наук. праць. 2011. Вип. 118. С. 107-112.

20. Житников В. П., Зайцев А. Н. Импульсная электрохимическая размерная обработка: монография. Москва: Машиностроение, 2008. 413 c.

\section{References}

1. Straka, L., Corny, I. and Pitel, J. (2016) Properties evaluation of thin microhardened surface layer of tool steel after wire EDM. Metals, 6 (5), p. 95.

2. Klocke, F., Hensgen, L., Klink, A., Ehle, L. and Schwedt, A. (2016) Structure and composition of the white layer in the wire-EDM process. Procedia CIRP, (42), pp. 673-678.

3. Debnath, S., Kundu, J. and Bhattacharyya, B. (2018) Modeling and influence of voltage and duty ratio on wire feed in WECM: possible alternative of WEDM. Journal of the Electrochemical Society, 165 (2), pp. E35-E44.

4. Zou, X., Fang, X., Chen, M. and Zhu, D. (2018) Investigation on mass transfer and dissolution localization of wire electrochemical machining using vibratory ribbed wire tools. Precision Engineering, (51), pp. 597-603.

5. Skoczypiec, S. (2016) Discussion of ultrashort voltage pulses electrochemical micromachining: a review. The International Journal of Advanced Manufacturing Technology, 87 (1-4), pp. 177-187.

6. Skoczypiec, S. and Ruszaj, A. (2014) A sequential electrochemical-electrodischarge process for micropart manufacturing. Precision Engineering, 38 (3), pp. 680-690.

7. Osipenko, V. I., Plakhotnyi, A. P. and Denisenko, A. Yu. (2014) Improved methodology for calculating the processes of surface anodic dissolution of spark eroded recast layer at electrochemical machining with wire electrode. Pratsi Odeskoho politekhnichnoho universytetu, 1 (43), pp. 55-60.

8. Taylor, E. J. and Inman, M. (2014) Electrochemical surface finishing. The Electrochemical Society Interface, 23 (3), pp. 57-61.

9. Zheng, X. H., Wei, Z. F. and Huang, S. (2013) Experiment study of pulse electrochemical finishing of $\mathrm{GCr} 15$ bearing steel. Advanced Materials Research, (705), pp. 203-208.
10. Kozak, J., Gulbinowicz, D. and Gulbinowicz,Z. (2008) The mathematical modeling and computer simulation of pulse electrochemical micromachining. Engineering Letters, 16 (4), pp. 556-561.

11. Kumsa, D. and Scherson, D. A. (2013) Theoretical aspects of pulsed electrochemical micromachining. Journal of the Electrochemical Society, 160 (8), pp. H481-H488.

12. Yang, G., Wang, B., Tawfiq, K., Wei, H., Zhou, S. and Chen, G. (2016) Electropolishing of surfaces: theory and applications. Surface Engineering, 33 (2), pp. 149-166.

13. Volosatov, V. A. (ed.) (1988) Reference book of electrophysical and electrochemical methods of processing. Moscow: Mashinostroenie. 719 p. [in Russian].

14. Smets, N., Van Damme, S., De Wilde, D., Weyns, G. and Deconinck, J. (2009) Timeaveraged concentration calculations in pulse electrochemical machining, spectral approach. Journal of applied electrochemistry, 39 (12), pp. 2481-2488.

15. Chin, D. T. (1983) Mass transfer and currentpotential relation in pulse electrolysis. Journal of the Electrochemical Society, 130 (8), pp. 1657-1667.

16. Bagotsky, V. S. (2005) Fundamentals of electrochemistry. John Wiley \& Sons, Inc.: Hoboken, NJ. 722 p.

17. Purushothaman, B., Morrison, P. and Landau, U. (2005) Reducing mass-transport limitations by application of special pulsed current modes. Journal of the Electrochemical Society, 152 (4), pp. J33-J39.

18. Choo, R., Toguri, J., El-Sherik, A. and Erb, U. (1995) Mass transfer and electrocrystallization analyses of nanocrystalline nickel production by pulse plating. Journal of applied electrochemistry, 25 (4), pp. 384-403.

19. Osipenko, V. I., Plakhotnyi, A. P. and Bilan, A. V. (2011) Investigation of material removal processes in electrochemical machining using wire electrode. Visnik SevNTU: coll. of sci. works, (118), pp. 107-112 [in Russian].

20. Zhitnikov, V. P. and Zaitsev, A. N. (2008) Pulse precision electrochemical machining. Moscow: Mashinostroenie, 413 p. [in Russian]. 
O. P. Plakhotnyi, Ph.D., associate professor, department of Energy Technology

Cherkasy State Technological University,

Shevchenko blvd, 460, Cherkasy, 18006, Ukraine

e-mail: pldecor@ukr.net

\section{MODELING OF INFLUENCE OF AMPLITUDE-TIME PARAMETERS OF ELECTRICAL PULSES ON ANODE DISSOLUTION PROCESSES IN WIRE ELECTROCHEMICAL MACHINING}

Combined technology of sequential use of electroerosive and electrochemical machining with wire electrode allows to obtain high-quality surface and to form metal components with high accuracy, regardless of material strength and hardness. Pulsed current in electrochemical machining greatly increases process controllability. The paper provides mathematical model of mass transfer in nearanode diffusion layer. This, together with calculation of current density distribution for a scheme with cylindrical cathode and flat anode, gives reasonable choice of amplitude-time parameters of electrical impulses. Such approach provides maximal current efficiency and precise prediction of removed layer thickness of surface obtained by a moving wire electrode. Conducted experimental researches on approbation of calculated method have shown that theoretical calculations are well consistent with experimental data. Proposed method allows to increase efficiency of electrochemical surface finishing after electroerosive cutting.

Keywords: wire electrical discharge machining, wire electrochemical machining, wire toolelectrode, inter-electrode spacing, surface phenomena, diffusion layer.

Стаття надійшла до редакиії 03.09.2018.

Рецензенти: Г. В. Канашевич, д.т.н., професор,

С. В. Поздєєв, д.т.н., професор. 